\title{
Occurrence and Population Densities of Yeast Species in the Digestive Tracts of Gulls and Terns
}

\author{
By S. KAWAKITA* AND N. VAN UDEN \\ Laboratory of Microbiology, Gulbenkian Institute \\ of Science, Oeiras, Portugal
}

(Received 11 November 1964)

\begin{abstract}
SUMMARY
From the intestinal tracts of 37 out of 69 birds belonging to four species of gulls (Larus fuscus, L. genei, L. argentatus, L. ridibundus) and three species of terns (Sterna sandvicensis, $S$. hirundo, $S$. minuta) 62 yeast isolates belonging to 16 species were obtained. The occurrences of individual yeast species were ( $\%$ of positive birds in brackets): Saccharomyces cerevisiae $(20 \%)$, Torulopsis glabrata (12\%), S. oleaginosus (10\%), Candida tropicalis $(9 \%)$, C. albicans $(9 \%)$ and $T$. pintolopesii $(7 \%)$, other yeast species (1-4\%). Average numbers of colony-forming units/g. wet intestinal contents in the seven host species were: Larus fuscus 5210; Larus genei 22,200 ; L. argentatus 5620 ; L. ridibundus 3180 ; Sterna sandvicensis 50; S. hirunda 211,$000 ; S$. minuta 9200.
\end{abstract}

\section{INTRODUCTION}

In recent years attention has been given to the intestinal yeast flora of several mammal and bird species (van Uden, 1963), but little to marine birds. High numbers of viable yeasts were found in the digestive tract of Larus occidentalis (Western Gull) by van Uden \& Castelo-Branco (1963). It was thought of interest to examine whether gulls and terns are, in general, suitable hosts for intestinal yeasts and to obtain information on the population densities and specific composition of their intestinal yeast flora. The possible role of marine birds in the dispersal of marine-occurring yeasts (Taysi \& van Uden, 1964; van Uden, 1964) gave additional stimulus to seeking such information. To be reported here are qualitative and quantitative findings on intestinal yeasts in 69 birds belonging to 7 species of gull and tern.

\section{METHODS}

Isolation medium (\%, w/v): glucose, 2; peptone (Difco), 1; yeast extract (Difco), 0.5 ; agar, 2 ; distilled water. The medium was adjusted to $\mathrm{pH} 4.5$ to discourage bacterial growth.

Isolation. Free-living gulls and terns were caught along the coast of Portugal and samples were taken from rectal contents. Weighed portions of the samples were suspended in sterile water and serial dilutions plated in $1 \mathrm{ml}$. volumes in isolation medium. After incubation at $37^{\circ}$ for $48-72 \mathrm{hr}$, the numbers of yeast colonies were recorded according to macroscopic and microscopic morphology. Representatives of each type were subcultured for later identification.

* Present address: Department of Microbiology, School of Medicine, Juntendo University, Tokyo, Japan. 
Identification of the yeast isolates. The methods described by Lodder \& Kregervan Rij (1952), Wickerham (1951), van Uden \& Farinha (1958), and Buckley \& van Uden (1963), were used.

\section{RESULTS}

Of 69 birds sampled, $\mathbf{3 7}$ harboured yeasts in detectable numbers. The total number of isolated strains was 62 , which corresponds to a total-yeast index (van Uden, 1960) of 0.9. These figures indicate that gulls and terns are hosts of medium suitability for intestinal yeasts, similar to other omnivorous host species (e.g. humans, swine; van Uden, 1960, 1963).

Table 1. Yeast species from the intestinal tracts of 69 gulls and terns

\begin{tabular}{|c|c|c|}
\hline Yeasts isolated & $\begin{array}{c}\text { No. of } \\
\text { birds } \\
\text { positive }\end{array}$ & $\begin{array}{c}\text { Percentag } \\
\text { incidence } \\
\text { of yeast } \\
\text { species }\end{array}$ \\
\hline Saccharomyces cerevisiae & 14 & 20 \\
\hline Torulopsis glabrata & 8 & 12 \\
\hline Saccharomyces oleaginosus & 7 & 10 \\
\hline Candida tropicalis & 6 & $\mathbf{9}$ \\
\hline C. albicans & 6 & $\boldsymbol{\theta}$ \\
\hline T. pintolopesii & 5 & 7 \\
\hline C. krusei & 3 & 4 \\
\hline C. norvegensis & $\mathbf{3}$ & 4 \\
\hline C. tenuis & $\mathbf{8}$ & 4 \\
\hline C. lusitaniae & 1 & $\mathbf{2}$ \\
\hline C. parapsilosis & $\mathbf{1}$ & $\mathbf{2}$ \\
\hline C. utilis & $\mathbf{1}$ & $\mathbf{2}$ \\
\hline T. famata & $\mathbf{1}$ & $\mathbf{2}$ \\
\hline Saccharomyces sp. & $\mathbf{1}$ & $\mathbf{2}$ \\
\hline Prototheca sp. & $\mathbf{1}$ & $\mathbf{2}$ \\
\hline
\end{tabular}

Table 2. Yeast population densities in the digestive tracts of 7 gull and tern species

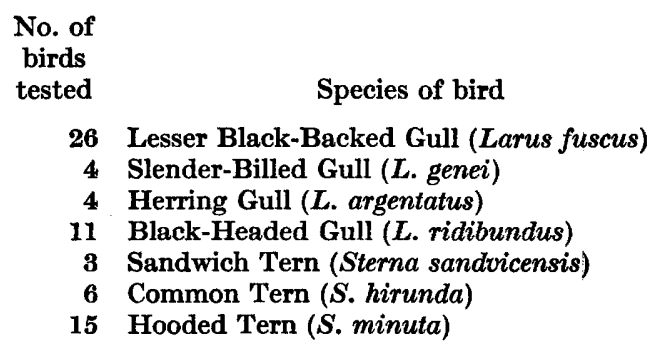

Tctal 69

\begin{tabular}{|c|c|c|c|c|}
\hline \multirow[b]{2}{*}{$\begin{array}{l}\text { No. of } \\
\text { birds } \\
\text { tested }\end{array}$} & \multirow[b]{2}{*}{ Species of bird } & \multirow{2}{*}{$\begin{array}{l}\text { No. of } \\
\text { birds } \\
\text { with } \\
\text { yeasts }\end{array}$} & \multicolumn{2}{|c|}{$\begin{array}{l}\text { Average numbers of } \\
\text { colony-forming units/g. wet } \\
\text { intestinal contents }\end{array}$} \\
\hline & & & $\begin{array}{l}\text { (a) Positive } \\
\text { birds }\end{array}$ & $\begin{array}{l}\text { (b) All } \\
\text { tested } \\
\text { birds }\end{array}$ \\
\hline 26 & Lesser Black-Backed Gull (Larus fuscus) & 12 & 11,280 & 5.210 \\
\hline 4 & Slender-Billed Gull (L. genei) & $\mathbf{3}$ & 29,600 & 22,200 \\
\hline 4 & Herring Gull (L. argentatus) & 1 & $\mathbf{2 2 , 5 0 0}$ & 5,600 \\
\hline 11 & Black-Headed Gull (L. ridibundus) & $\mathbf{5}$ & 7,000 & 3,180 \\
\hline $\mathbf{3}$ & Sandwich Tern (Sterna sandvicensis) & 2 & 70 & $\mathbf{5 0}$ \\
\hline 6 & Common Tern (S. hirunda) & $\mathbf{5}$ & 253,100 & 211,000 \\
\hline 15 & Hooded Tern (S. minuta) & $\mathbf{9}$ & 11,500 & $\mathbf{9 , 2 0 0}$ \\
\hline 69 & & 37 & 44,600 & $\mathbf{2 3 , 9 0 0}$ \\
\hline
\end{tabular}

The species of yeast isolated and their respective incidences are listed in Table 1. The six most frequently isolated species included Torulopsis glabrata and Candida tropicalis. These two species were also predominant in a group of Western Gulls 
studied earlier (van Uden \& Castelo-Branco, 1963). In the present survey Saccharomyces cerevisiae was the most frequent species. Van Uden \& Carmo-Sousa (1962) found that this yeast was capable of multiplication in the digestive tract of swine and must be regarded as a facultative intestinal saprophyte. T. glabrata and

Table 3. Occurrence and population densities of yeast species in the digestive tracts of 7 gull and tern species

Slender-Billed Gull (L. genei)

Herring Gull (L. argentatus)

Black-Headed Gull (L. ridibundus)

Sandwich Tern (Sterna sandvicensis) Common Tern (S. hirundo)

Hooded Tern (S. minuta)

Sandwich Tern
(Sterna sandvicensis)
Common Tern
(S. hirundo)

No. of

$\begin{array}{ll}\text { No. of } & \begin{array}{c}\text { No. of } \\ \text { birds }\end{array} \\ \text { birds } & \text { with }\end{array}$

tested

26

yeasts

12

4

4

11

6

15
Yeast species

Candida albicans

Saccharomyces cerevisiae

Torulopsis glabrata

C. tropicalis

C. krusei

C. norvegensis

T. pintolopesii

S. oleaginosus

3

C. norvegensis

C. parapsilosis

C. tropicalis

T. pintolopesii

T. glabrata

S. oleaginosus

T. glabrata

T. pintolopesii

C. krusei

S. cerevisiae

Saccharomyces sp.

\section{No. of \\ birds \\ with \\ species}

5

4

3

2

1

1

1

1

1

1

1

1

1

$\mathbf{1}$

1

1

5

T. glabrata

T. pintolopesii

C. albicans

C. Iusitaniae

C. tenuis

S. cerevisiae

Trichosporon capitatum

$\mathbf{2}$

C. tropicalis

S. cerevisiae

5

T. glabrata

C. tropicalis

C. krusei

C. norvegensis

$S$. oleaginosus

9

C. tropicalis

C. utilis

C. tenuis

T. candida

S. oleaginosus

S. cerevisiae

Prototheca sp.
Average population density of each yeast species in the digestive tracts of the birds harbouring this species (colonyforming units/g. wet intestinal contents)

26,716

35

135

49

48

1,110

25

13

33,916

2,796

1,004

11,000

24,667

15,417

2,800

200

200

19,000

300

890

6,850

1,770

620

22,500

2,060

295

40

60

134,880

78,680

880,000

10

57,373

240

640

3,000

6,700

31,850

10,053

300 
C. albicans are polyspecific obligatory intestinal saprophytes with potential pathogenicity; they occur in a wide range of hosts (van Uden, 1963). The occurrence of the oligospecific $\boldsymbol{T}$. pintolopesii in gulls and terns is surprising since this yeast is known as an obligatory saprophyte of small rodents; however, it has also been obtained from pigeons (van Uden, 1960). Saccharomyces oleaginosus (S. italicus var. melibiosi) is probably a facultative intestinal saprophyte; it was isolated previously from humans and horses (van Uden \& Assis-Lopes, 1957) and from swine (van Uden \& Carmo-Sousa, 1962). Outside the animal body this yeast is frequent in the watery discharge from fermenting stacked olives (Santa Maria, 1963).

The average number of colony-forming units/g. wet intestinal contents was 44,600 for the 37 birds which harboured yeasts at all, and 23,900 for the total of 69 birds studied (Table 2). Among the seven host species the yeast population densities varied between 50 and 211,000 colony-forming units/g. wet intestinal contents. Whether this wide range of population densities is indicative of differences in host suitability for yeasts between the bird species cannot be ascertained from the relatively small numbers of specimens tested within each host species. Nevertheless, the yeast species distribution among the birds and their respective population densities (Table 3) suggest that host suitability for intestinal yeasts is a property of gulls and terns as a group rather than of certain species of these birds.

Gulls and terns must inoculate yeasts with their faeces into natural water bodies the world over. Torulopsis glabrata, Candida tropicalis, C. krusei, and other yeasts which occur in these birds, have been encountered in tropical and subtropical marine water bodies as predominant yeasts (Fell \& van Uden, 1963; van Uden \& Castelo-Branco, 1963; van Uden, 1964). In temperate and cold-water bodies such intestinal yeasts have so far not been detected, regardless of the presence of gulls and terns or other sources of intestinal yeasts (sewage). There is some evidence that intestinal yeasts are outgrown in temperate and cold-water bodies by yeasts which have lower cardinal temperatures (Taysi \& van Uden, 1964).

Thanks are due to Dr G. Ferraz de Carvalho, Department of Zoology, University of Lisbon, for the identification of the birds.

\section{REFERENCES}

BuCkLey, H. R. \& vaN UdEN, N. (1963). The identification of Candida albicans within two hours by the use of an egg white slide preparation. Sabouraudia, 2, 205.

Fell, J. \& vaN UdeN, N. (1963). Yeasts in marine environments. In Oppenheimer, C. H. (ed.), Symposium on Marine Microbiology, pp. 329-40. Springfield, Ill.: C. C. Thomas.

Lodder, J. \& Kreger-van RIJ, N. J. W. (1952). The Yeasts. Amsterdam: North-Holland Publishing Company.

Santa Maria, J. (1963). Sacch. oleaginosus (van Uden \& Assis-Lopes) Santa Maria (basionym Sacch. italicus Castelli var. melibiosi van Uden \& Assis-Lopes, nov.var.). Bol. Inst. Invest. Agron. Madr. 48, 17.

TAYsi, I. \& VAN UDEN, N. (1964). Occurrence and population densities of yeast species in an estuarine-marine area. Limnol. Oceanog. 9, 42.

vAN UDEN, N. (1960). The occurrence of Candida and other yeasts in the intestinal tracts of animals. Ann. N.Y. Acad. Sci. 89, 59.

van Uden, N. (1963). Factors of host-yeast relationship. In Recent Progress in Microbiology, 8, 635. Toronto: University of Toronto Press. 
VAN UdEN, N. (1964). On the occurrence and origin of yeasts in estuaries. Conference on Estuaries, Jekyll Island, Georgia, 31 March-4 April (in preparation).

vaN Uden, N. \& Assis-Lopes, L. (1957). Fermentation of raffinose in the absence of invertase by Saccharomyces italicus Castelli var. melibiosi nov.var. Portug. Acta Biol. A, 4, 323.

van Uden, N. \& Carmo-Sousa, L. Do (1962). Quantitative aspects of the intestinal yeast flora of swine. J. gen. Microbiol. 27, 35.

van Uden, N. \& Castelo-Branco, R. (1963). Distribution and population densities of yeast species in Pacific water, air, animals, and kelp off Southern California. Limnol. Oceanog. 8, 323.

VAN UdEN, N. \& FARINHA, M. (1958). On the significance of temperature relations and vitamin deficiency patterns in the delimitation of yeast species. Portug. Acta Biol. B, 6,161 .

Wickerham, L. J. (1951). Taxonomy of yeasts. Tech. Bull. U.S. Dep. Agric. no. 1029. 